\title{
Immunoregulation of natural and lymphokine-activated killer cells by selenium
}

\author{
Madhavan P. N. Nair and Stanley A. Schwartz \\ Departments of Pediatrics, Epidemiology and Psychiatry, I09 S. Observatory, Rm. 3073 SPH-I. The University of Michigan, Ann \\ Arbor, MI 48109-2029, U.S.A.
}

(Received 9 November 1989; accepted 8 February 1990)

\begin{abstract}
The effect of selenium (Se) on natural killer (NK) and lymphokine-activated killer (LAK) cell activities and proliferative responses of human lymphocytes was studied in vitro. Direct addition of Se at $1.0 \mu \mathrm{g} / \mathrm{ml}$ final concentration to the mixture of target and effector cells during a $4 \mathrm{~h}$ cytotoxicity assay significantly suppressed the NK activity of normal lymphocytes. When lymphocytes were preincubated with Se at concentrations as low as $0.2 \mu \mathrm{g} / \mathrm{ml}$ for a period of $48 \mathrm{~h}$, a significant inhibitory effect on NK activity was observed. In the LAK cell assay, direct addition of Se at concentrations of $0.2-1.0 \mu \mathrm{g} / \mathrm{ml}$ to a mixture of target and effector cells did not show any effects on LAK cell activity, whereas LAK cells generated in the presence of Se at $0.8 \mu \mathrm{g} / \mathrm{ml}$ showed significant inhibition of their functions. Lymphocyte proliferative responses to $\mathrm{T}$ cell mitogens such as phytohemagglutinin (PHA) and concanavalin A (Con A) were also significantly suppressed by direct addition of Se at $0.5-1.0 \mu \mathrm{g} / \mathrm{ml}$. The inhibitory effect of Se was not duc to nonspecific toxicity of effector cells as demonstrated by viability nor was the effect directed against target cells. These studies suggest that although Se is an essential micronutrient for various immune mechanisms, an excess of Se may have a deleterious effect on certain immunological functions. As these activities are considered to be important defense mechanisms against tumors and virus infections, a nutritional imbalance of Se could result in an increased risk of these disorders.
\end{abstract}

Key words: Cytotoxicity; Lymphokine-activated cytotoxicity; Lymphocyte proliferation; Selenium, suppression by

\section{Introduction}

Nutrition plays an important role in host responses to various infections and carcinogens (Yang et al., 1987; Reddy et al., 1980; Byers et al., 1984). Several studies have indicated that immunodeficiency or defective immunoregulation, such as reduced natural killer (NK) and lymphokine-activated killer (LAK) cells, increased suppressor or decreased helper cell activities, or altered $\mathrm{T}$ and $\mathrm{B}$ cell responses, is associated with cancer (Herberman et al., 1978; Rosen-

Correspondence: Madhavan P.N. Nair, Ph.D., The University of Michigan, Ann Arbor, MI 48109-2029, U.S.A.

Abbreviations: Se, selenium; LAK, lymphokine-activated killer cells; NK, natural killer cells; PHA, phytohemagglutinin; Con A, concanavalin A; PBMC, peripheral blood mononuclear cells; PBL, peripheral blood lymphocytes. berg et al., 1986; Whong-Peng et al., 1978). Like zinc $(\mathrm{Zn})$ and copper $(\mathrm{Cu})$, selenium $(\mathrm{Se})$ is an accepted micronutrient with established RDAs (Mertz et al., 1986). Previous studies have shown that Se deficiency resulted in down-regulation of various immune functions such as lymphocyte proliferative response to various mitogens (Eskew et al., 1985; Parnharn et al., 1983; Sheffy et al., 1979), polyclonal B cell activation (Chandra et al., 1982) and granulocyte (Urban et al., 1986) and cytotoxic cell (Kiremidjian-Schumacher et al., 1987; Petrie et al., 1989a) activities, and supplementation of Se was associated with restoration of certain depressed immune functions (Petrie et al., 1989b; Arvilommi et al., 1983; Spallholz et al., 1981; Koller et a1., 1986). A recent study suggests that Se can effectively inhibit mixed lymphocyte culture reactions and in vitro 
lymphocyte responses to tetanus toxoid (Petrie et al., 1986). The effect of Se imbalance on immune functions has not been extensively examined, especially its effects on the cytotoxic activities of NK and LAK cells. The present study examines the effects of Se (as sodium selenite) on NK, LAK and lymphocyte proliferative responses.

\section{Materials and Methods}

\section{Media}

'Complete medium' consisted of RPMI 1640 (GIBCO, Grand Island, NY), with $25 \mathrm{mM}$ HEPES buffer, $80 \mu \mathrm{g} / \mathrm{ml}$ gentamicin (Schering Corp., Kenilworth, NJ), $300 \mu \mathrm{g}$ of fresh glutamine $/ \mathrm{ml}$, and $10 \%$ heat-inactivated fetal calf serum $(\mathrm{v} / \mathrm{v})$.

\section{Isolation of lymphocytes}

Peripheral blood mononuclear cells (PBMC) were isolated from heparinized $(20 \mathrm{U} / \mathrm{ml})$ venous blood from healthy normal donors using a modified method of Boyum (Boyum, 1968). Blood was diluted with an equal volume of normal saline and centrifuged at $400 \times g$ for $30 \mathrm{~min}$ at $18^{\circ} \mathrm{C}$. The mononuclear cell band was harvested, washed three times with saline, and resuspended in complete medium as described (Nair et al., 1988).

\section{Depletion of adherent cells}

PBMC were suspended in complete medium and depleted of adherent cells by passage through a $7 \mathrm{ml}$ column of Sephadex G-10 beads (Pharmacia Fine Chemicals, Piscataway, NJ) and equilibrated in complete medium as previously described (Nair et al., 1988). After $45 \mathrm{~min}$ of incubation at $37^{\circ} \mathrm{C}$, nonadherent peripheral blood lymphocytes (PBL) were eluted with 1 bed volume of medium at $37^{\circ} \mathrm{C}$. Cell recovery was $>70 \%$ of the total input, and monocyte contamination, as indicated by nonspecific esterase staining, was $<2 \%$.

\section{Assays for $N K$ and $L A K$ cell activities}

LAK and NK cell activities were determined in a direct ${ }^{51} \mathrm{Cr}$-release assay as described previously (Nair et al., 1981, 1988). The human myeloid cell line, K562, was used as target for NK cells because it is highly susceptible to NK activity (West et al.. 1977). For the LAK cell assay we chose as target a human B cell leukemia line, SB, because of its resistance to NK activity in a $4 \mathrm{~h}$ assay (Koren et al., 1978). Briefly, varying concentrations of viable effector cells in complete medium were added to triplicate cultures of ${ }^{51} \mathrm{Cr}$-labeled target cells in $0.2 \mathrm{ml}$ volumes in $\mathrm{V}$-bottom microtitration plates (Dynatech Labs, Alexandria, VA). After centrifugation at $40 \times g$ for $2 \mathrm{~min}$, the cells were incubated at $37^{\circ} \mathrm{C}$ in a humidified atmosphere of $5 \% \mathrm{CO}_{2}$ in air for $4 \mathrm{~h}$. Percent cytotoxicity was calculated as follows:

$\%$ Cytotoxicity $=$

experimental release - spontaneous release total release - spontaneous release $\times 100$

where total release represents counts obtained in an aliquot of $2 \times 10^{4}$ lysed target cells, and spontaneous release represents counts obtained from control wells containing only $2 \times 10^{4}$ target cells and media during $4 \mathrm{~h}$ incubation. The spontaneous release from target cells was always less than $5 \%$ of the total release.

\section{Generation of $L A K$ cells}

Commercially available recombinant IL2 alpha (Collaborative Research, Inc., Bedford, MA) was diluted in complete medium and stored at $-70^{\circ} \mathrm{C}$ before use. IL2 concentrations of $5-10 \mathrm{U} / \mathrm{ml}$ in complete medium were used to generate LAK cells. PBL were activated to generate LAK cells by incubation for 4 days in LAK medium containing Se at concentrations ranging from 0.01 to $1 \mu \mathrm{g} / \mathrm{ml}$ in upright $25 \mathrm{~cm}^{2}$ flasks at a density of $1 \times 10^{6}$ cells $\mathrm{ml}$ at $37^{\circ} \mathrm{C}$ in a $5 \% \mathrm{CO}_{2} / 95 \%$ air atmosphere as described (Nair et al., 1988).

\section{Lymphocyte proliferation assay}

This assay was performed as described (Nair et al., 1988). Briefly, $2 \times 10^{5}$ PBMC were cultured in complete medium containing $10 \%$ fetal calf serum in sterile U-bottom microtitration plates (Dynatech, Alexandria, VA). Specific cultures received Se at concentrations of $0.2-1 \mu \mathrm{g} / \mathrm{ml}$. Lymphocyte activators such as PHA $(2.5 .5$ and $10 \mu \mathrm{g} / \mathrm{ml})$ and Con 
A $(1,2.5$ and $5 \mu \mathrm{g} / \mathrm{ml})$ were added to Se-containing cultures and incubated for $72 \mathrm{~h}$ at $37^{\circ} \mathrm{C}$ in a $5 \%$ $\mathrm{CO}_{2}$ /air incubator. Control cultures containing varying concentrations of Se or PHA alone were examined concomitantly. One $\mu \mathrm{Ci}$ of $\left[{ }^{3} \mathrm{H}\right]$ thymidine ( $1 \mathrm{Ci}$ $=37 \mathrm{GBq}$ ) was added to each well during the last $24 \mathrm{~h}$ of incubation. The cultures were collected by an automated cell harvester and incorporation of $\left[{ }^{3} \mathrm{H}\right]$ thymidine into lymphocyte DNA was determined with a Beckman Model LS700 scintillation counter. Results are expressed as cpm per $2 \times 10^{5}$ cells.

\section{Statistical analysis}

The significance of differences between control and experimental values was determined by a paired Student's ' $t$ ' test.

\section{Results}

Effect of selenium on $N K$ and $L A K$ cell activities of lymphocytes

Data presented in Table I demonstrate the viability of lymphocytes cultured in various concentrations of Se for 48 and $96 \mathrm{~h}$ respectively for NK and LAK cells as measured by the trypan blue dye exclusion technique. Lymphocytes cultured in complete medium for $48 \mathrm{~h}$ with $1 \mu \mathrm{g} / \mathrm{ml}$ of Se were $92 \%$ viable. Lymphocytes cultured in IL2-containing medium

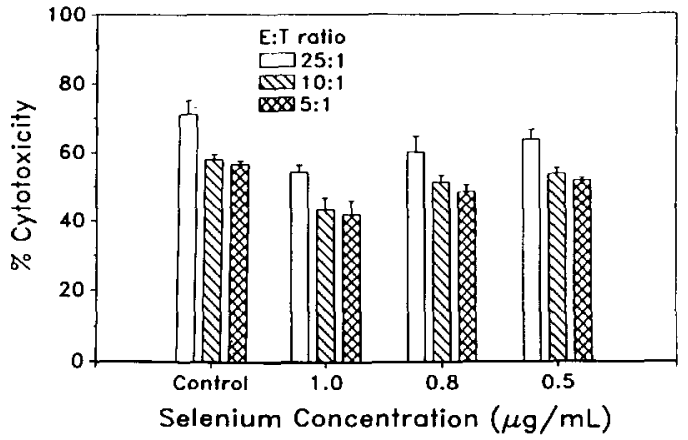

Fig. 1. Effect of Se on NK activity. Se was added directly to the reaction mixture of effector and target cells (K562) and NK activity was measured as described. Results are expressed as mean $\%$ cytotoxicity \pm SDM of a single experiment performed in triplicate. Three other experiments produced similar results. The variation of cytotoxicity produced in the 4 different experiments using 4 different lymphocyte samples was in the range 5 to $15 \%$ at 25:1 effector-to-target (E:T) cell ratios. Similar levels of variations occurred with other E:T cell ratios. However, in all experiments, Se at a concentration of $1 \mu \mathrm{g} / \mathrm{ml}$ produced significant suppression compared to control lymphocytes analysed by paired ' $f$ ' test.

to generate LAK cells demonstrated $100 \%$ viability at the end of $96 \mathrm{~h}$ of culture. Se at all tested concentrations produced levels of viability similar to those of control cultures. This demonstrates that Se at a concentration of up to $1 \mu \mathrm{g} / \mathrm{ml}$ is not toxic to the cells.

Fig. 1 shows the effect of Se on NK activity when added directly to the target-effector cell mixture. Cytotoxicity was dependent upon the number of ef-

\section{TABLE I}

Effect of selenium on NK activity of lymphocytes

\begin{tabular}{|c|c|c|c|c|c|}
\hline \multirow{2}{*}{$\begin{array}{l}\text { Source of } \\
\text { effector cells }\end{array}$} & \multicolumn{5}{|c|}{ Selenium concentrations $(\mu \mathrm{g} / \mathrm{ml})$} \\
\hline & 0 & 1 & 0.5 & 0.2 & 0.1 \\
\hline NK & $95.4 \pm 3.0$ & $\begin{array}{l}92.0 \pm 4.0 \\
(p<0.4)\end{array}$ & $\begin{array}{l}90.5 \pm 2.0 \\
(p<0.25)\end{array}$ & $\begin{array}{l}89.6 \pm 7.0 \\
(p<0.25)\end{array}$ & $\begin{array}{l}98.7 \pm 5.7 \\
(p<0.4)\end{array}$ \\
\hline LAK & $98.2 \pm 4.0$ & $\begin{array}{l}93.3 \pm 7.0 \\
(p<0.4)\end{array}$ & $\begin{array}{l}90.6 \pm 3.2 \\
(p<0.1)\end{array}$ & $\begin{array}{l}91.7 \pm 5.0 \\
(p<0.1)\end{array}$ & $\begin{array}{l}100.0 \pm 2.1 \\
(p<0.4)\end{array}$ \\
\hline
\end{tabular}

Data are presented as percent viability.

$1 \times 10^{6}$ PBL depleted of adherent cells were cultured for 48 to $96 \mathrm{~h}$ in medium containing varying concentrations of Se and tested for their viability by the trypan blue dye exclusion assay. The concentration of Se in the control medium varied from 0.001 to $0.005 \mu \mathrm{g} / \mathrm{m} 1$. The data presented are means $\pm \mathrm{SD}$ of 4 experiments performed in triplicate. The statistical significances were calculated by paired ' $t$ ' test. 
fector cells used, and the inhibitory effect of Se occurred at all effector-to-target (E:T) cell ratios. Se at lower concentrations $(0.5$ and $0.8 \mu \mathrm{g} / \mathrm{ml})$ did not produce significant inhibitory effects on NK activity; however, significant suppression of $\mathrm{NK}$ activity was observed at $1 \mu \mathrm{g} / \mathrm{ml}(p<0.005, p<0.02$ and $p$ $<0.02$ respectively at 25:1, 10:1 and 5:1 E:T cell ratios).

The data in Fig. 2 demonstrate the effect of preculture of lymphocytes with Se for $48 \mathrm{~h}$ on their NK activity. A prior kinetic analysis (data not presented) showed that a minimum incubation period of 48 $\mathrm{h}$ was necessary for Se to effect significant inhibition of NK activity against K562 target cells. Se at 0.2 $\mu \mathrm{g} / \mathrm{ml}$ produced significant suppression of $\mathrm{NK}$ activity at all $E: T$ cell ratios examined with resultant cytotoxicities of $65 \%(p<0.01), 46 \%(p<0.002)$ and $20 \%(p<0.003)$ at $\mathrm{E}: \mathrm{T}$ ratios of $50: 1,25: 1$ and 10:1 respectively; $p$ values are relative to differences between control cultures without added Se. This inhibition was more pronounced at higher Se concentrations. For example, Se at $0.5 \mu \mathrm{g} / \mathrm{ml}$ produced $41 \%(p<0.0), 24 \%(p<0.001)$ and $8 \%(p<$ 0.001 ) cytotoxicity compared to $70 \%, 60 \%$ and $31 \%$ cytotoxicity produced by control cultures respectively at 50:1, 25:1 and 10:1 E:T cell ratios. Se at $1 \mu \mathrm{g} / \mathrm{ml}$ produced very significant suppression of cytotoxicity, which was negligible at this concentration.

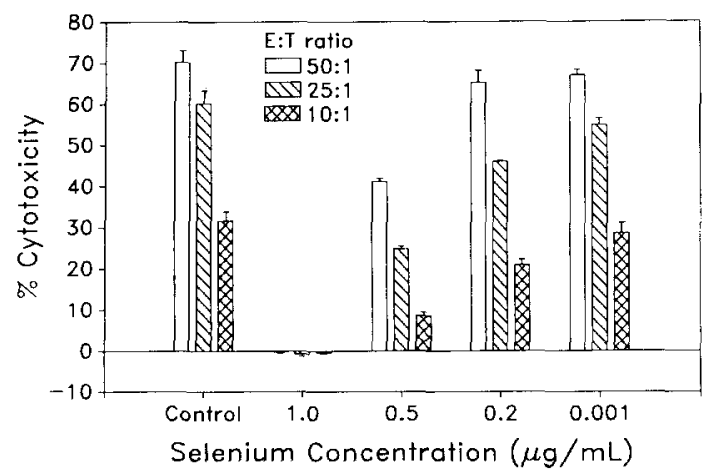

Fig. 2. NK Activity of lymphocytes preincubated with Se. $1 \times$ $10^{6} \mathrm{PBL} / \mathrm{ml}$ were incubated with varying concentrations of $\mathrm{Se}$ for $48 \mathrm{~h}$ at $37^{\circ} \mathrm{C}$, washed and tested for NK activity against prelabeled $\mathrm{K} 562$ target cells at varying $\mathrm{E}: \mathrm{T}$ cell ratios. Values represent mean \% cytotoxicity \pm SDM of a single experiment performed in triplicate. Three other experiments produced similar results.
Experiments were undertaken to investigate whether Se directly affects the activity and generation of LAK cells. Direct addition of Se at concentrations ranging from 0.2 to $1.0 \mu \mathrm{g} / \mathrm{ml}$ to a mixture of effector and target cells did not affect the lytic activity of LAK cells during a $4 \mathrm{~h}$ assay period (data not presented). Fig. 3 shows the cytotoxic activity of LAK cells generated for $96 \mathrm{~h}$ in the presence of different concentrations of Se against NK-nonsensitive SB target cells. Se at $0.8 \mu \mathrm{g} / \mathrm{ml}$ significantly inhibited LAK cell induction, yielding cytotoxicities of $65 \%(p<0.01), 45 \%(p<0.03)$ and $8 \%(p<$ 0.03 ) compared to $86 \%, 67 \%$ and $17 \%$ cytotoxicities manifested by control cultures respectively at 10:1, 5:1 and 1:1 E:T cell ratios. Se at $1 \mu \mathrm{g} / \mathrm{ml} \mathrm{dem-}$ onstrated $66 \%(p<0.01), 38 \%(p<0.03)$ and $8 \%$ $(p<0.03)$ cytotoxicity versus cytotoxicities of $86 \%, 67 \%$ and $17 \%$ produced by control cultures at $10: 1,5: 1$ and $1: 1 \mathrm{E}: \mathrm{T}$ cell ratios respectively.

\section{Effect of Se on lymphocyte proliferative responses to mitogens}

Previous work by others suggested that Se deficiency impairs lymphocyte proliferative responses to various mitogens (Eskew et al., 1985; Parnharn et al., 1983; Sheffy et al., 1979) and polyclonal B cell activation (Chandra et al., 1982). Thus we investigated the effects of excess Se on lymphocyte prolif-

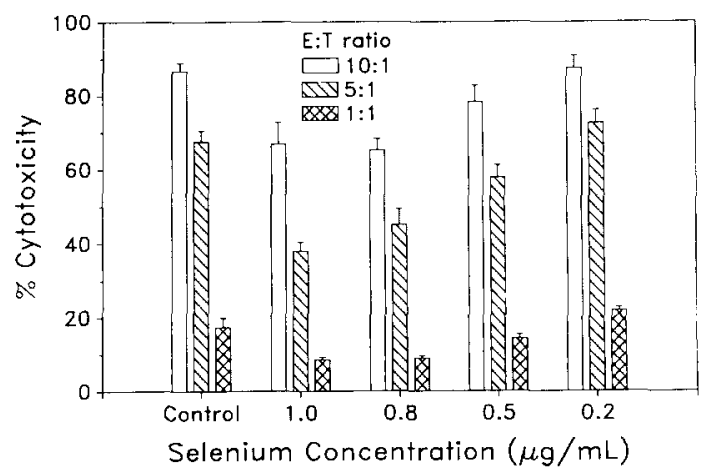

Fig. 3. Effect of Se on LAK cell functions. $1 \times 10^{6} \mathrm{PBL}$ were cultured in IL2-containing medium together with varying concentrations of Se for $96 \mathrm{~h}$, washed and tested for cytotoxic activity against NK-resistant SB target cells. Values represent mean $\%$ cytotoxicity \pm SDM of a single experiment performed in triplicate. Four other experiments produced similar results. 
erative responses to the $\mathrm{T}$ cell mitogens, PHA and Con A. Data presented in Fig. 4 demonstrate that PHA at 5 and $2.5 \mu \mathrm{g} / \mathrm{ml}$ produced significant proliferative responses $(104,176 \mathrm{cpm}$ and $70,048 \mathrm{cpm}$ respectively) which were significantly suppressed by $\mathrm{Se}$ in a dose-dependent manner. At a concentration of $0.6 \mu \mathrm{g} / \mathrm{ml}$, Se yielded reduced counts of 37,527 cpm $(p<0.01)$ and 10,481 cpm $(p<0.004)$ respectively at 5.0 and $2.5 \mu \mathrm{g} / \mathrm{ml}$ of PHA. At $0.8 \mu \mathrm{g} \mathrm{Se} / \mathrm{ml}$ counts were further reduced to $23,353 \mathrm{cpm}(p<$ $0.001)$ and $6,606 \mathrm{cpm}(p<0.007)$ at 5.0 and 2.5 $\mu \mathrm{g} / \mathrm{ml}$ of PHA respectively. A Se concentration of $1.0 \mu \mathrm{g} / \mathrm{ml}$ virtually completely inhibited PHA stimulated mitogenesis.

As shown in Fig. 5, Se produced a similar dosedependent inhibition of Con A-induced proliferation. Suppression of responses to $5.0 \mu \mathrm{g} / \mathrm{ml}$ of Con A was significant at Se concentrations of $0.6(p<$ $0.001), 0.8(p<0.006)$ and $1(p<0.007) \mu \mathrm{g} / \mathrm{ml}$.

\section{Discussion}

NK and LAK cells are involved in host defense against tumors and virus infections and in the regu-

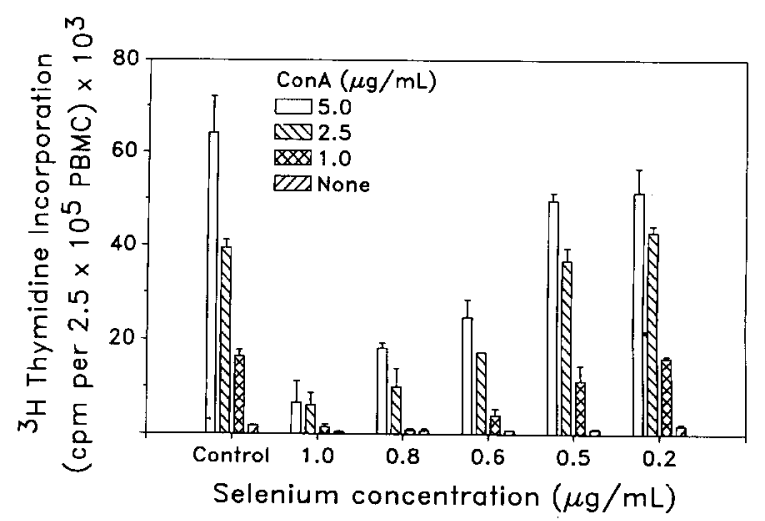

Fig. 4. Effect of Se on lymphocyte proliferative responses to PHA. PBMC $\left(2 \times 10^{5}\right)$ from healthy individuals were cultured with either PHA or PHA + different concentrations of Se for 72 h. $\left[{ }^{3} \mathrm{H}\right]$ Thymidine $(1 \mu \mathrm{Ci})$ was added to each well during the last $24 \mathrm{~h}$ of culture and cells were harvested on glass-fiber filters. Radioactivity was measured in a liquid scintillation counter and expressed as cpm per $2 \times 10^{5}$ PBMC. Results are expressed as the mean cpm \pm SEM of triplicate values from one representative experiment. Three other experiments produced similar results. lation of several lymphocyte activities (Herberman et al., 1978; Rosenberg et al., 1986; Whong-Peng et al., 1978; Nair et al., 1981, 1988). Numerous epidemiological and experimental investigations suggest that Se has an anticarcinogenic effect (Schrauzer et al., 1977; Reddy et al., 1988; Uark 1985; Kobayashi et al., 1986; Willett et al., 1983; Thomson et al., 1984). By contrast, it has also been shown that rats fed Se (4 ppm) during the post-initiation phase of carcinogenesis demonstrated enhanced development of colon cancer (Jacobs et al., 1981). Reddy et al. (1988) observed an increased incidence of small intestinal tumors induced by carcinogen in rats fed an excess of Se, but Se deficiency inhibited colon tumorigenesis. Various investigators have noted that Se deficiency can result in impaired mitogenic responses of lymphocytes (Eskew et al., 1985; Sheffy et al., 1979), decreased numbers and function of neutrophils and macrophages (Urban et al., 1986; Gyang et al., 1984; Boyne et al., 1979; Serfass et al., 1976; Talcott et al., 1984; Willett et al., 1988; Oldfield 1987), and diminished antibody-producing cells (Chandra et al., 1982). Talcott et al. (1984) reported that NK activity was stimulated slightly in female Sprague-Dawley rats given $2 \mathrm{ppm}$ of Se. Ip and Ip (1981) found no alterations of in vitro immune functions such as mitogen stimulation or natural killer cell activities of lymphocytes from rats fed supra-nutritional levels of Se. Koller et al. (1986) showed that Se administered to rats in lower doses $(0.5-2.0 \mathrm{ppm})$ significantly enhanced splenic

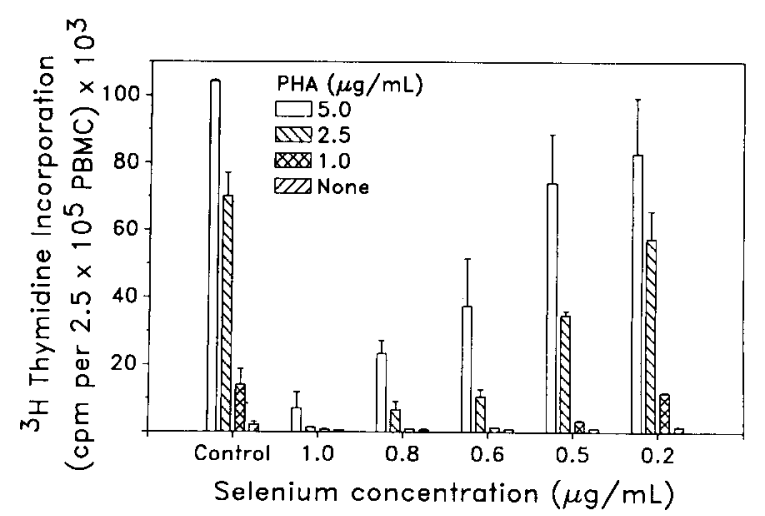

Fig. 5. Effect of Se on Con A-induced lymphocyte proliferative response. $2 \times 10^{5}$ PBMC were cultured with Con $\mathrm{A}$ as described in the legend for Fig. 4. 
NK activity, while no change was observed at higher concentrations of Se. Further, rats fed lower as well as higher Se levels manifested suppressed delayed hypersensitivity responses, while antibody synthesis was inhibited only at the highest Se levels. This suggests that Se can exert both stimulatory and inhibitory effects at various concentrations. Thus this dichotomy of effects of Se on various immune responses and tumorigenesis is not clearly understood and has been the subject of various reviews (Willett et al., 1988; Oldfield 1987). The immunological alterations observed in these studies may be due to selective depletion or homing of certain lymphocyte subpopulations to various lymphoid organs depending upon Se deficiency or excess. Alternatively Se may directly affect lymphocyte functions or modulate them by selective activation or inhibition of various immunoregulatory cell subpopulations. Current investigations may resolve these questions.

Se levels in various tissues vary considerably, with hair having the highest levels. A blood level of $3.2 \mu \mathrm{g} / \mathrm{ml}$ and a urine level of $2.68 \mu \mathrm{g} / \mathrm{ml}$ have been noted in chronic selenosis (Levander, 1985). We report herein that $\mathrm{Se}$, at lower concentrations than reported in selenosis (e.g. $0.5-1 \mu \mathrm{g} / \mathrm{ml}$ ), significantly suppresses NK and LAK cell activities and the proliferative responses of normal lymphocytes. The reduced NK and LAK cell activities observed in Sesupplemented media were not due to direct toxicity of effector cells, because lymphocytes cultured in Se-supplemented media showed viability similar to control cultures without added Se. Further, equal numbers of viable effector cells were consistently used for control and Se-supplemented cultures for all assays. Experiments were also undertaken to examine whether inhibition of cytotoxicity was due to increased resistance of target cells to lysis after treatment with Se. Target cells were labeled with ${ }^{51} \mathrm{Cr}$, preincubated with $\mathrm{Se}$, washed and used in NK cell assays. The results demonstrated that preincubation of targets with Se did not affect their sensitivity to lysis by effector cells (data not presented). In assays where effector cells were precultured in Se-containing medium, Se was removed after washing and the washed effector cells were then mixed with target cells, thus minimizing the carryover of Se to the mixture. These studies suggest that the effect of Se appears to be directly or indirectly on effector cells and not on target cells.

The exact mechanisms by which NK or LAK cell functions are affected in vitro by excess Se are not understood. Several explanations may underlie this suppression, including: (1) induction of cells capable of inhibiting NK/LAK cell functions; (2) decreased ability to recruit $\mathrm{NK} / \mathrm{LAK}$ cells from precursors; (3) reduced production of NK/LAKcell-stimulating lymphokines (e.g., interferon/interleukin 2); (4) decreased production of cytotoxic factor; (5) failure of helper cell activation; (6) blocking of $\mathrm{NK} / \mathrm{LAK}$ cell receptors, thus minimizing target binding; and/or (7) altered levels of reactive oxygen metabolites such as hydrogen peroxide, hydroxyl radical, or other oxygen intermediates which are believed to be involved in mediating cytotoxic reactions (Nathan, 1982). These possibilities remain to be investigated. Thus, excess levels of Se as reported herein interfere with the cytotoxic functions of $\mathrm{NK}$ and LAK cells. To achieve an effective antitumor response in adoptive immunotherapy against malignancy, using IL2 or LAK cells, special consideration should be given to the blood Se levels of these patients.

\section{Acknowledgement}

This work was supported, in part, by NIH Grant No. RO1 CA35922.

\section{References}

Arvilommi H, Poikonen K, Jokinen I, Muukkanen O, Rasanen L, Foreman J, Huttunen JK. Selenium and immune functions in humans. Infect Immunol 1983;41:185.

Boyne R, Arthur JR. Alterations of neutrophil function in selenium-deficient cattle. J Comp Pathol 1979;89:151.

Boyum A. Isolation of mononuclear cells and granulocytes from human blood. Isolation of mononuclear cells by one centrifugation and of granulocytes by combining centrifugation and sedimentation. J Clin Lab Invest 1968;21(suppl 97):77.

Byers T, Graham S. The epidemiology of diet and cancer. Adv Cancer Res 1984:41:1. 
Chandra RK, Dayton DH. Trace element regulation of immunity and infection. Nutr Res 1982;2:721.

Eskew ML, Scholz RW, Readdy CC, Todhunter DA, Zarko A. Effects of vitamin $E$ and selenium deficiencies on rat immune functions. Immunology 1985;54:173.

Gyang EO, Stevens JB, Olson WG, Tsitsamis SD, Usenik EA. Effect of selenium-vitamin E injection on bovine polymorphonucleated leukocytes, phagocytosis and killing of Staphylococcus aureus. Am J Vet Res 1984;45:175.

Herberman RB, Holden J. Natural cell mediated immunity. Adv Can Res 1978;27:305.

Ip C, Ip MM. Chemoprevention of mammary tumorigenesis by a combined regimen of selenium an vitamin $\mathrm{A}$. Carcinogenesis 1981;2:2915.

Jacobs MM, Frost CF, Beams FA. Biochemical and clinical effects of selenium on dimethylhydrazine-induced colon cancer in rats. Cancer Res 1981;41:4458.

Kiremidjian-Schumacher L, Stotzky G. Selenium and immune response. Environ Res 1987;72:277.

Kobayashi M, Kogata M, Yamamura M, Takada H, Hioki Yamamoto $\mathrm{M}$. Inhibitory effect of dietary selenium on carcinogenesis in rat glandular stomach induced by $N$-methyl- $N$-nitro-N-nitrosoguanidine. Cancer Res 1986;46:2266.

Koller LD, Exon JH, Talcott PA, Osborne CA, Henningsen GM. Immune responses in rats supplemented with selenium. Clin Exp Immunol 1986;63:570.

Koren HS, Amos DB, Kim YB. Natural killer and antibody dependent cellular cytotoxicity are independent immune functions in the Minnesota Miniature Swine. Proc Natl Acad Sci USA 1978;75:5127.

Levander OA. Considerations on the assessment of selenium status. Fed Proc 1985;44:2579.

Mertz W. Trace elements in human and animal nutrition, Vol 2, 5th edn. New York: Academic Press, 1986.

Nair MPN, Schwartz SA. Suppression of natural killer activity and antibody-dependent cellular cytotoxicity by cultured human lymphocytes. J Immunol 1981;125:2221.

Nair MPN, Schwartz SA. Immunoregulation of lymphokine activated killer cells. Clin Immunol Immunopathol 1988;49:28.

Nair MPN, Pottathil R, Heimer EP, Schwartz SA. Immunoregulatory activities of human immunodeficiency virus (HIV) proteins. Effect of HIV recombinant and synthetic peptides on immunoglobulin synthesis and proliferative responses by normal lymphocytes. Proc Natl Acad Sci USA 1981;85:6498.

Nathan CF. Secretion of oxygen intermediates: role in effector functions of activated macrophages. Fed Proc 1982;41:2206.

Oldfield JE. The two faces of selenium. J Nutr 1987;117:2002.

Parnharn MJ, Winkelman J, Keyck S. Macrophage, lymphocyte and chronic inflammatory responses in selenium deficient rodents. Association with decreased glutathione peroxidase activity. Int J Immunopharmacol 1983;5;455.

Petrie HT, Klassen LW, Tempero MA, Kay HD. In vitro regulation of human lymphocyte proliferation by selenium. Biol Trace Elem Res 1986;11:129.
Petrie HT, Klassen LW, Kay HD. Selenium and the immune response. I. Modulation of alloreactive human lymphocyte functions in vitro. J Leukocyte Biol 1989a;45:207.

Petrie HT, Lassen LW, Klassen PS, O'Dell JR, Kay D. Selenium and the immune response. 2. Enhancement of murine cytotoxic $\mathrm{T}$ lymphocyte and natural killer cell cytotoxicity in vivo. $\mathrm{J}$ Leukocyte Biol. 1989b;45:215.

Reddy BS, Cohen LA, McCoy DG, Hill P, Weisburger JH, Wynder EL. Nutrition and its relationship to cancer. Adv Cancer Res 1980;32:327.

Reddy B, Sugie S, Maruyama S, Marra P. Effect of dietary excess of inorganic selenium during initiation and post initiation phases of colon carcinogenesis in F344 rats. Cancer Res 1988;48:1777.

Rosenberg SA, Speiss P, Lafreneire R. A new approach to the adoptive immunotherapy of cancer with tumor infiltrating lymphocytes. Science 1986;233:1318.

Schrauzer GN, White DA, Schneider CJ. Cancer mortality correlation studies. III. Statistical associations with dietary selenium intakes. Bioinorganic Chem 1987;7:23.

Serfass RE, Ganther HE. Effects of dietary selenium and tocopherol on glutathione peroxidase and superoxide dismutase activities in rat phagocytes. Life Sci 1976;19:1139.

Sheffy BE, Schultz RD. Influence of vitamin $E$ and selenium on immune response mechanisms. Fed Proc 1979;38:2139.

Spallholz JE. Anti-inflammatory immunologic and carcinostatic attributes of selenium in experimental animals. Adv Exp Med Biol. 1981;135:43.

Talcott PA, Exon JH, Koller LD. Alteration of natural killer cell mediated cytotoxicity in rats treated with selenium, diethylnitrosamine and ethylnitrosamine. Cancer Lett 1984;23:313.

Thomson HJ, Meeker LD, Kokosa S. Effect of an inorganic and organic form of dietary selenium on the promotional stage of mammary carcinogenesis in the rat. Cancer Res 1984;44:2803.

Uark LC. The epidemiology of selenium and cancer. Fed Proc 1985:44:4584.

Urban T, Jarstrand C. Selenium effects on human neutrophilic granulocyte function in vitro. Immunopharmacology 1986;12:167.

West WH, Cannon GB, Kay HD, Bonnard DG, Herberman RB. Natural cytotoxic activity reactivity of human lymphocytes against a myeloid cell line. Characterization of effector cells. J Immunol 1977; I 18:355.

Whong-Peng J, Durm M, Goldman C, Muul L, Waldmann T, Broder S, Poplack D. Characterization of a suppressor-cell leukemia. N Engl J Med 1978;298:66.

Willett WC, Morris JS, Pressel S, Taylor JD. Prediagnostic serum selenium and risk of cancer. Lancet 1983:16:130.

Willett WC, Stampfer M. Selenium and cancer. Whether selenium protects against cancer is still unknown. $\mathrm{Br}$ Med $\mathrm{J}$ 1988;297:573.

Yang CS, Newmark HL. The role of micronutrient deficiency in carcinogenesis. Crit Rev Oncol Hematol 1987;7:267. 